tion in volcanic products would necessarily result from either source of supply, and that if the central-fluid theory is to be maintained, it must be for other and less fanciful reasons than those hitherto adduced. I quite agree with the remark that it has been rather assumed that geologists believe in a fluid interior with a solid crust. They probably believe nothing of the kind, for, like other inquirers accustomed to scientific investigations, they are not disposed to adopt a belief, unless it be grounded on well-ascertained facts; and as there now exists but little faith in mere opinions of great authorities, it would appear that in the present phase of the question, the most satisfactory state of mind would be one of pure scepticism.

S. Aluport.

\title{
CORRELATION OF THE SCOTCH AND ENGLISH DRIFTS.
}

SrR,-As I have probably devoted more time to the examination of the drifts of the N.W. of England than any other observer, a few remarks from me seem to be called for by Mr. James Geikie's article in your last number. While very willing to acknowledge the great value of his contributions to Post-tertiary geology, I cannot agree with him in regarding all the drifts of the above area as subordinate varieties of one great formation; for the more these deposits are investigated, the more one becomes convinced of the classificatory value of the well-defined and more or less persistent sub-divisions they present.

The blue clay of the W. Riding of Yorkshire, Cumberland, and $\mathrm{N}$. Wales, is not only distinct in colour, and in the character of most of its included stones, from the other clays, but it must have been subjected to great denudation, leaving a deeply-undulating or hummocky surface, before the lower brown clay was deposited. The latter (though it embraces a considerable variety) differs in its general colour, composition, and relative proportion of local and erratic stones, the number of large boulders, etc., from the upper clay; and its surface generally undulates as if it had been extensively denuded; while the surface of the upper clay is in most places a dead flat. The gravel-and-sand formation between the two clays is not a series of intercalations, but as persistent a deposit as either of the clays. It has to a great extent been derived from local rocks, and the number of erratic stones it contains is much smaller than in the clay above or below. Its surface must have been deeply denuded before the upper clay was deposited, as Professor Hull and Mr. De Rance have shown. In the neighbourhood of hills it generally rises up from beneath the upper clay, and forms a series of knolls or ridges. There are few sand-and-gravel knolls that are not capped with decided Upper Boulder-clay, ${ }^{1}$ or show indications of having once been more or less covered with this clay. I do not believe that in the area under consideration there are any sand or gravel knolls overlying decided Upper Boulder-clay, though they may occasionally come above a subordinate clay bed of the middle drift, or a thin bed

I In the neighbourhood of Oswestry there are striking instances of high and abrupt gravel-and-sand knolls capped with upper boulder-clay. 
of local Lower Boulder-clay. The more the subject is investigated, the more one becomes convinced that the Upper Boulder-elay is the newest glacial or interglacial deposit in the N.W. of England.

The shell-bearing gravel-and-sand around Macclesfield, which according to Mr. Sainter (Grou. MAG., Vol. II., pp. 366, 368) ranges from 600 to 1200 feet above the sea-level, is I believe an upward extension of the middle drift of the plain of Cheshire. The deposit on Moel-y-Tryfan is not so finely stratified, and the stones are not so much rounded as in the gravel at lower levels; but it agrees with the gravel-and-sand of Anglesey in the large boulders being found at its base (though a few are scattered through its mass), and with the Cheshire and Lancashire middle drift in the character of many of its erratics, including Eskdale and Criffell granite, chalk-flints, etc. Mr. Darbishire says it is capped with clay (GroL. Mag., Vol. II., p. 295); though this I missed seeing.

The following is the sequence of the drift deposits of the N.W. of England and a part of Wales (order descending) :-

Red clay, with grey or blue partings; rather few stones and exceedingly few large boulders; more or less marly in its lower part; extensively used for bricks. Maximum thickness unknown.

Gravel and sand, with subordinate beds of elay and loam. Maximum thickness in Cumberland 120 feet; at Gresford, near Wrexham, 150 feet; at Kersal Moor, Lancashire, 200 feet (Hull). ${ }^{1}$

Madder-brown clay, with subordinate beds of laminated loam, seams, pockets, and lenticulations of sand; numerous stones, and at intervals many large boulders; vertical or oblique fractures; often rudely stratified; graduating into a still harder, more gritty, and stony clay, with a tendency to arched stratification, in the neighbourhood of the hills (Pinel); in general not well adapted for bricks. Maximum thickness at Lindal, Furness, 120 feet.

Blue or greyish-blue clay, with many stones and at intervals many boulders. Maximum thickness at Colwyn, N. Wales, not less than 60 feet.

The above drifts have been found to be shell-bearing with the exception of the blue clay and the pinel. The best sections may be seen on the sea-coast.

D. Mackintosh.

\section{MR. W. $\$$. MITCHELL ON THE "DENUDATION OF THE BATH OOLITE."}

SIR,-I believe Mr. Mitchell is of opinion that the hills of Bath Oolite were simply old coral-reefs, and did not owe their form to denudation. (See Quart. Journ. Geol. Soc., 1871, vol. xxvii., p. 228.)

I was staying near Bath in the Spring of 1869, and discovered, in a shallow excavation on the left of the road on Kingsdown, beyond Bathford, some beautiful specimens of Oolitic Corals-the finest which have been obtained from the neighbourhood of Baththe best of which I gave to Mr. Charles Moore, for the Bath Museum. They consisted of several genera and species, and occurred at one portion of the excavation; the space which they occupied being a few yards across, and appearing to be a section of a small coral reef, bounded on each side by the usual limestone. It is possible this bed increases in width, vertically.

Corals appear to be of rare general occurrence in the Bath hills ;

1 In the Vale of York this formation is associated with deposits of finely laminated clay of various colours. 